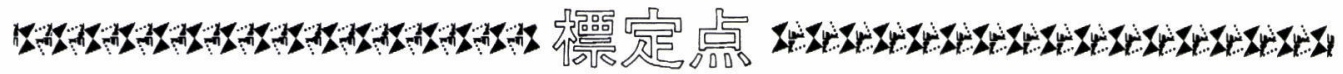

\section{GIS 空間データ基盤整備について}

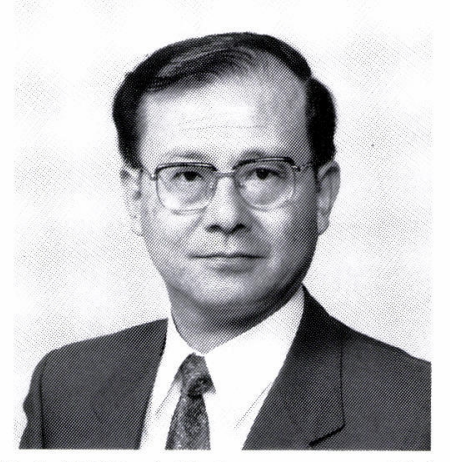

平成 7 年 1 年間におけるパソコンの販売台数が 530 万台を越えそうだという記事を目にしましたが，事業 所や家庭へのパソコンの普及は著しいものがあるよj です。いよいよ情報化社会の到来といった感がありま す。こうなりますと, 社会で共通に必要とされる情報 自体がインフラストラクチュアであるとの指摘がされ るようになります。科学技術等各分野で使われるデー タベースについては勿論でありますが, 地理情報シス テムの基礎デー夕となる数值地困情報の整備を求める 声が高まっております。米国では, 国家情報インフラ (NII) 整備構想が提唱され, このなかで地理情報にも 大きな力点がおかれています。わが国においては，阪 神・淡路大震災を契機として地理情報システムの有効 性が注目されるとともに，空間デー夕整備の必要性が 強く主張されるようになりました。コンピューターで 扱える数值地図デー夕の整備には, 大きな経費を要す ることと，そのデー夕が広く社会の様々な分野で活用 できることから，公的な機関による整備が求められて いるように思われます。

これまで国土地理院においては, 国土数值情報, 宅 地利用動向調查(細密数值情報), 基本図数值情報, ディ ジタルマッピングの標準化, 白地図データベース技術 基準の制定, 国土基本図データベース等, 数值地図情 報整備に関する事業を実施してきました。とりわけ 1993年から刊行を開始した数值地図のシリーズは，フ ロッピーディスクで一般に提供したことから当初の予 想を上回る需要があり, 各種の利用ソフトがでまわっ ているようです。これらの事業により，種々の情報し

「写真測量とリモートセンシング」Vol. 34, No. 6, 1995
建設省国土地理院院長 和里田 義 雄

ベルの数值地理情報を提供してきましたが，地理情報 システムでの活用のために必要とされる空間デー夕基 盤は，大縮尺地図に相当する情報レベルで大都市地域 を広くカバーしたデータとして整備することが求めら れております。

今年になって，地理情報システムの整備の必要性が 広く意識されるようになり，政府部内でもこれに対応 した検討が行われるようになっております。地理情報 システムは，国あるいは地方自治体の行政にもおおい に活用できるものであるところから，政府として地理 情報システムの整備を推進するため, 内閣内政審議室 を事務局として GIS 関係省庁連絡会議が設置されま した。また建設省としても省内に空間デー夕基盤整備 委員会を設置し，さらに GIS の整備活用方策を検討す るため有識者を委員とする GIS 研究会を発足させ, 目 下活発な活動を進めているところであります。

国土地理院は，GISのためのデー夕整備を今後の事 業の大きな柱の一つとして取り組んでいくこととし， 平成 7 年度の第 2 次補正予算において首都圈と近畿圈 の既成市街地・近郊整備地带等について GIS 空間デー 夕基盤整備を実施しております。作業の特徴としては, 大縮尺地図に相当する数值地図情報を短期間に比較的 広域にデー夕作成すること,デー夕作成項目は, GIS の 基盤情報として必要な項目（行政区域，街区，道路中 心線，公共建物等）に絞っていること，デー夕はGIS での利用を考えて必要な構造化がなされていることな どであります。また,デー夕の提供についてもユーザー の幅広い利用を考慮して CD-ROM で提供することを 検討中であります。

このような大規模なデー夕整備を短期間に実施する ことは, 国土地理院としても初めてでありますが，作 成されたデー夕が多方面に活用されるような仕様と, 出来る限り効率的なデー夕作成方法を鋭意検討してい るところであります。この GIS 空間デー夕基盤が広く 使われ，わが国における GIS の普及に打扔いに貢献す ることを期待いたしております。 